\title{
Enantioselective Diels-Alder reaction of anthracene by chiral tritylium catalysis
}

\author{
Qichao Zhang ${ }^{1}$, Jian Lv ${ }^{* 1,2}$ and Sanzhong Luo ${ }^{* 1,3}$
}

\author{
Full Research Paper \\ Address: \\ ${ }^{1}$ Key Laboratory of Molecular Recognition and Function, Institute of \\ Chemistry, Chinese Academy of Sciences, 100190, Beijing, China, \\ ${ }^{2}$ State Key Laboratory Base of Eco-Chemical Engineering, College of \\ Chemistry and Molecular Engineering, Qingdao University of Science \\ \& Technology, 266042, Qingdao, China and ${ }^{3}$ Center of Basic \\ Molecular Science (CBMS), Department of Chemistry, Tsinghua \\ University, 100084, Beijing, China \\ Email: \\ Jian Lv* - Ivjian@iccas.ac.cn; Sanzhong Luo* - \\ luosz@tsinghua.edu.cn \\ * Corresponding author
}

Keywords:

anthracene; carbocation catalysis; Diels-Alder reaction; Fe(III)-based phosphate anion; tritylium salt
Beilstein J. Org. Chem. 2019, 15, 1304-1312.

doi:10.3762/bjoc. 15.129

Received: 12 February 2019

Accepted: 24 May 2019

Published: 14 June 2019

This article is part of the thematic issue "Reactive intermediates carbocations".

Guest Editor: S. R. Hare

(c) 2019 Zhang et al.; licensee Beilstein-Institut.

License and terms: see end of document.

\section{Abstract}

The combination of the trityl cation and a chiral weakly coordinating Fe(III)-based bisphosphate anion was used to develop a new type of a highly active carbocation Lewis acid catalyst. The stereocontrol potential of the chiral tritylium ion pair was demonstrated by its application in an enantioselective Diels-Alder reaction of anthracene.

\section{Introduction}

Carbocation Lewis acid catalysis has grown significantly over the last two decades [1-13]. The development of asymmetric carbocation catalysts has been long pursued but remains a challenging task. One strategy is to design and synthesize stabilized chiral carbocations with chirality installed onto their backbones. Pioneering efforts along this line by Kagan, Sammakia, and Chen have shown that chiral catalysis with such chiral carbocations was indeed plausible to achieve stereocontrol (Scheme 1a). [14-19]. However, the enantioselectivity was low in most cases. In addition, the synthetic efforts to access these chiral cations were generally non-trivial which limited their further development. Recently, we developed a chiral ion-pair strategy for asymmetric carbocation catalysis, with chiral trityl phosphate as the carbocation precursor [20,21]. In this latent strategy, the carbocation precursor can undergo facile ionic dissociation upon mild external stimulation such as polar substrates (such as $\alpha$-ketoesters) to form a catalytically active chiral ion pair for substrate activation and chiral induction (Scheme 1b). In our further explorations, we noticed that the dissociation of trityl phosphate was generally sluggish, thus 
a) chiral carbocations with chiral skeleton

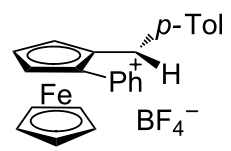

Kagan [15]

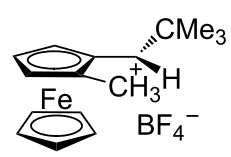

Sammakia [16]<smiles>CCC1c2ccccc2[C+](c2ccccc2)c2ccccc21</smiles>

Chen [17]

b) our asymmetric latent carbocation catalysis: an ion pair strategy

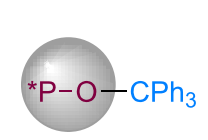

trityl phosphate (TP) latent carbocation

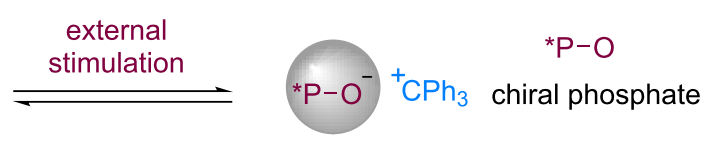

chiral carbocation pair

- 2015, substrate stimulation with chiral phosphate anion

c) this work: with $\mathrm{Fe}(\mathrm{III})$-complexed phosphate anion

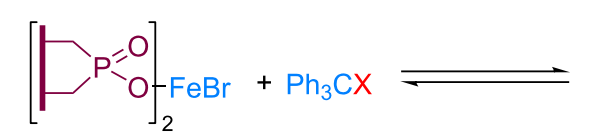

$\mathrm{Ph}_{3} \mathrm{C}^{+}\left[\mathrm{P}_{\mathrm{O}}^{=\mathrm{O}}\right]_{2}^{\mathrm{FeBr}}$

chiral weakly coordinating

chiral Lewis acid $\mathrm{Fe}(\mathrm{III})$-based phosphate anion

Scheme 1: Asymmetric carbocation catalysis.

limiting its applicability. To expand its utility, we report herein a metal-complexed phosphate anion for chiral carbocation catalysis.

Weakly coordinating anions $[22,23]$ have been widely used in inorganic and organic chemistry [24-27] as well as in polymer chemistry [28-33]. Although tritylium salts with various types of these counter anions based on B(III), $\mathrm{Al}(\mathrm{III}), \mathrm{Ga}(\mathrm{III}), \mathrm{Fe}(\mathrm{III})$, $\mathrm{Nb}(\mathrm{III}), \mathrm{Ta}(\mathrm{III}), \mathrm{Y}(\mathrm{III})$ and $\mathrm{La}(\mathrm{III})$ centers and ligands have been investigated in Lewis acid catalysis over the past decades, a chiral counter anion [34,35] with metal elements as the central atom, however, was seldom reported. Typically, the tritylium salts with weakly coordinating anions can be synthesized through a simple halide abstraction from the trityl halide in the presence of strong Lewis acids [36]. We herein report the design and exploration of a new trityl carbocation that has a chiral weakly coordinating Fe(III)-based phosphate anion for the effective asymmetric catalysis in the Diels-Alder reaction of anthracenes.

\section{Results and Discussion}

In our previous work, we found that less than $6 \%$ of trityl phosphate (TP) dissociated to trityl cations in the presence of a polar substrate such trifluoropyruvate [20]. In order to improve the efficiency of the dissociation, we started by first studying the properties of tritylium salts with a weakly coordinating metalbased phosphate anion (Scheme 2). Upon in situ mixing the chiral trityl phosphate (TP, $0.05 \mathrm{mM})$ and different Lewis acids $(0.05 \mathrm{mM})$, such as $\mathrm{InCl}_{3}, \mathrm{InBr}_{3}, \mathrm{InI}_{3}, \mathrm{In}(\mathrm{OTf})_{3}, \mathrm{Sc}(\mathrm{OTf})_{3}$, $\mathrm{Hf}(\mathrm{OTf})_{3}, \mathrm{GaCl}_{3}$, and $\mathrm{FeBr}_{3}$, the originally colorless solution of the chiral trityl phosphate TP turned orange, suggesting the formation of tritylium ions (Scheme 2a). The stimulated trityl cation generation was probed by UV-vis spectroscopy. As shown in Figure 1a, when treated with different Lewis acids, trityl phosphate $\mathbf{T P}$ showed a variable tendency to dissociate into the free tritylium ion pair with $\mathrm{InBr}_{3}$ as the most active Lewis acid. An estimation based on UV absorption showed that approximately $76 \%$ of TP dissociated into trityl cations in the presence of $\mathrm{InBr}_{3}$. On the other hand, tritylium salts with a weakly coordinating metal-based monophosphate or bisphosphate anion could also be obtained when trityl bromide was treated with the corresponding metal phosphate, which can be prepared in situ following our previously described procedure (Scheme 2b,c) [37,38]. UV analysis indicated that the indium salt 1a or gallium salt $1 \mathbf{b}(0.05 \mathrm{mM})$ could induce ca. $92 \%$ dissociation of trityl bromide $(0.05 \mathrm{mM})$ to generate the trityl cation. Also, $\mathrm{FeBr}_{3}$, a chiral $\mathrm{Fe}(\mathrm{III})$ monophosphate $\left(\mathrm{M}=\mathrm{FeBr}_{2}\right) \mathbf{1 c}$ or even the bulky $\mathrm{Fe}(\mathrm{III})$ bisphosphate $\mathbf{2 a}$ 

a) $\mathrm{Ph}_{3} \mathrm{COPA}^{*}+\mathrm{LA} \underset{\mathrm{rt}}{\stackrel{\mathrm{CH}_{2} \mathrm{Cl}_{2}}{\longrightarrow}}\left[\mathrm{Ph}_{3} \mathrm{C}\right]\left[\mathrm{LA}\left(\mathrm{OPA}{ }^{*}\right)\right]$
b) $\mathrm{Ph}_{3} \mathrm{CX}+\mathrm{LA}\left(\mathrm{OPA}^{*}\right)_{n} \stackrel{\mathrm{CH}_{2} \mathrm{Cl}_{2}}{\mathrm{rt}}\left[\mathrm{Ph}_{3} \mathrm{C}\right]\left[\mathrm{LA}\left(\mathrm{OPA}^{*}\right)_{n} \mathrm{X}\right]$
C) $\left(\mathrm{OPA}^{*}\right)_{n}=$
$n=1, \mathrm{Ar}=4-\mathrm{PhC}_{6} \mathrm{H}_{4}$
TP: $\mathrm{M}=\mathrm{CPh}_{3}$
1a: $M=\operatorname{lnBr} 2$
$n=2, \mathrm{M}=\mathrm{FeBr}$
1b: $\mathrm{M}=\mathrm{GaCl}_{2}$
a: $\mathrm{Ar}=4-\mathrm{PhC}_{6} \mathrm{H}_{4}$
1c: $\mathrm{M}=\mathrm{FeBr}_{2}$
2b: $\mathrm{Ar}=2,4,6-\left(\mathrm{CH}_{3}\right)_{3} \mathrm{C}_{6} \mathrm{H}_{2}$
1d: $\mathrm{M}=\mathrm{BCl}_{2}$
2c: $\mathrm{Ar}=\mathrm{Ph}_{3} \mathrm{Si}$
2d: $A r=C_{6} F_{5}$
1e: $\mathrm{M}=\mathrm{AlCl}_{2} \quad$ 2e: $\mathrm{Ar}=4-(1$-naphthyl $) \mathrm{C}_{6} \mathrm{H}_{4}$
1f: $\mathrm{M}=\mathrm{YCl}_{2} \quad$ 2f: $\mathrm{Ar}=4$-(2-naphthyl) $\mathrm{C}_{6} \mathrm{H}_{4}$
1g: $\mathrm{M}=\mathrm{HfCl}_{3}$

Scheme 2: Synthesis of new carbocation catalysts with weakly coordinating metal-based phosphate anion.

a)

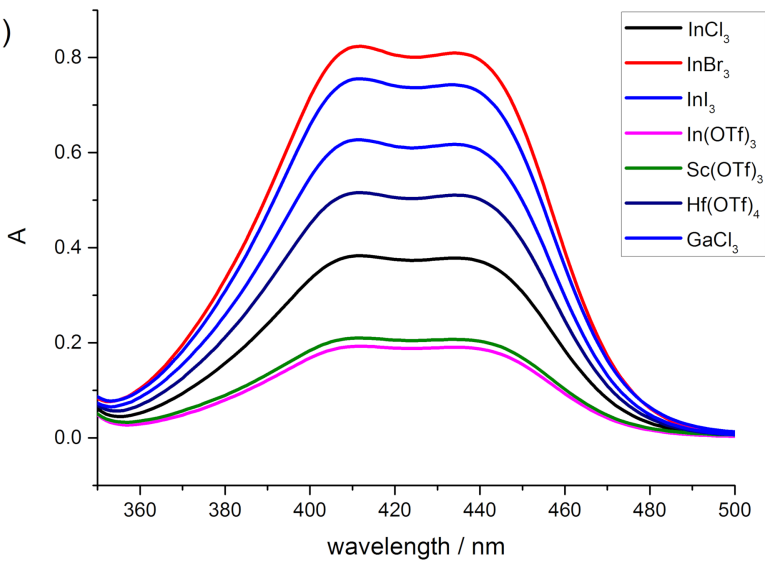

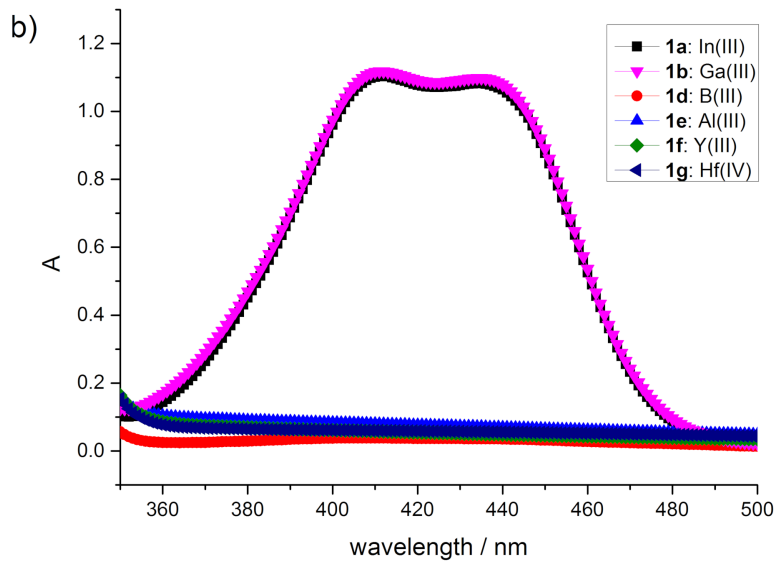

Figure 1: Dissociation of latent carbocation by the use of Lewis acids. a) UV-vis absorption spectra of TP (0.05 mM) upon the addition of Lewis acids $(0.05 \mathrm{mM})$, such as $\operatorname{InCl}_{3}, \operatorname{InBr}_{3}, \operatorname{Inl}_{3}, \operatorname{In}(\mathrm{OTf})_{3}, \mathrm{Sc}(\mathrm{OTf})_{3}, \mathrm{Hf}(\mathrm{OTf})_{4}$, and $\mathrm{GaCl}_{3}$. b) UV-vis absorption spectra of trityl bromide $\left(\mathrm{Ph}{ }_{3} \mathrm{CBr}\right.$, $\left.0.05 \mathrm{mM}\right)$ upon the addition of the chiral Lewis acids $(0.05 \mathrm{mM})$, such as $\mathbf{1 a}, \mathbf{b}$, and $\mathbf{d}-\mathbf{g}$

promoted the dissociation of trityl bromide. In the latter case, the dissociation was estimated to be $54 \%$ by in-situ IR spectroscopy (UV-vis spectra were not applicable due to absorption overlap; see Supporting Information File 1 for details).

We next tested the metal phosphate strategy in the Diels-Alder reaction of anthracene, for which a catalytic asymmetric version has not been achieved yet. Recently, we reported that the tritylium salt $\left[\mathrm{Ph}_{3} \mathrm{C}\right][\mathrm{BArF}]$, in situ generated by $\mathrm{Ph}_{3} \mathrm{CBr}$ and $\mathrm{NaBArF}$, could promote the Diels-Alder reaction with anthracenes and various unsaturated carbonyl compounds under mild conditions [13]. The use of latent carbocation catalysis with TP was examined in order to achieve enantioselective control. To our delight, TP catalyzed the asymmetric reaction affording cycloadduct $\mathbf{5 a}$ in excellent enantioselectivity ( $97 \%$ ee), however, with only $9 \%$ yield (Table 1 , entry 1 ) Subsequent efforts to improve the activity by enhancing the dissociation efficiency of latent carbocation through heating or photolysis did not lead to any improvement. We next investigated whether the tritylium salts with a chiral weakly coordinating metal-based phosphate anion could facilitate the asymmetric catalytic Diels-Alder reaction. To implement this strategy, different trityl phosphates or halides, Lewis acids, chiral metal phosphate and their combinations were examined in the model reaction of anthracene (3a) and $\beta, \gamma$-unsaturated $\alpha$-ketoester $4 \mathbf{a}$. When TP was first treated with metal Lewis acid (Scheme 2a, and Table S1 in Supporting Information File 1), the reaction showed good reactivity but no enantioselectivity at all, indicating a strong background reaction (Table 1, entry 2). We next examined the second strategy in which trityl bromide was treated with preformed chiral metal phosphate to their equilibration before they were subjected to the catalytic test. When metal monophosphates 1a-c (Table 1, entries 3-5) were applied, the reaction started showing some enantioselectivity with decent 
Table 1: Screening and optimization for the asymmetric catalyzed Diels-Alder reaction of anthracene by carbocations.

\begin{tabular}{|c|c|c|c|c|c|}
\hline \multirow[t]{2}{*}{ entry ${ }^{a}$} & \multicolumn{2}{|c|}{ carbocation } & \multirow[t]{2}{*}{ solvent } & \multirow[t]{2}{*}{ yield $(\%)^{b}$} & \multirow[t]{2}{*}{$e e^{c}$} \\
\hline & $\operatorname{Tr} X$ & Lewis acid & & & \\
\hline 1 & TP & none & DCE & 9 & 97 \\
\hline \multicolumn{6}{|c|}{ metal-based monophosphate anion } \\
\hline 2 & TP & $\mathrm{InBr}_{3}$ & DCE & 94 & rac \\
\hline 3 & $\mathrm{Ph}_{3} \mathrm{CBr}$ & $1 \mathrm{a}$ & DCE & 55 & 14 \\
\hline 4 & $\mathrm{Ph}_{3} \mathrm{CBr}$ & $1 b$ & DCE & 49 & -16 \\
\hline 5 & $\mathrm{Ph}_{3} \mathrm{CBr}$ & $1 c$ & DCE & 79 & 36 \\
\hline \multicolumn{6}{|c|}{$\mathrm{Fe}(\mathrm{III})$-based bisphosphate anion } \\
\hline 6 & $\mathrm{Ph}_{3} \mathrm{CBr}$ & $2 a$ & DCE & 46 & 40 \\
\hline 7 & $\mathrm{Ph}_{3} \mathrm{CBr}$ & $2 a$ & DCM & 58 & 56 \\
\hline 8 & $\mathrm{Ph}_{3} \mathrm{CBr}$ & $2 a$ & $\mathrm{CHCl}_{3}$ & 36 & 42 \\
\hline 9 & $\mathrm{Ph}_{3} \mathrm{CBr}$ & $2 a$ & toluene & 20 & 46 \\
\hline 10 & $\mathrm{Ph}_{3} \mathrm{CBr}$ & $2 a$ & $\mathrm{CH}_{3} \mathrm{CN}$ & $\mathrm{nr}$ & - \\
\hline 11 & $\mathrm{Ph}_{3} \mathrm{CBr}$ & $2 b$ & $\mathrm{DCM}$ & 17 & 14 \\
\hline 12 & $\mathrm{Ph}_{3} \mathrm{CBr}$ & $2 c$ & DCM & 55 & 28 \\
\hline 13 & $\mathrm{Ph}_{3} \mathrm{CBr}$ & $2 d$ & DCM & 67 & 26 \\
\hline 14 & $\mathrm{Ph}_{3} \mathrm{CBr}$ & $2 e$ & DCM & 22 & 68 \\
\hline 15 & $\mathrm{Ph}_{3} \mathrm{CBr}$ & $2 f$ & DCM & 70 & 74 \\
\hline $16^{d}$ & $\mathrm{Ph}_{3} \mathrm{CBr}$ & $2 f$ & DCM & 55 & 90 \\
\hline $17^{d}$ & $\mathrm{Ph}_{3} \mathrm{CCl}$ & $2 f$ & DCM & 57 & 91 \\
\hline $18^{\mathrm{d}, \mathrm{e}}$ & $\mathrm{Ph}_{3} \mathrm{CCl}$ & $2 f$ & DCM & 70 & 91 \\
\hline $19^{d}$ & none & $2 f$ & DCM & $\mathrm{nr}$ & - \\
\hline $20^{d}$ & $\mathrm{Ph}_{3} \mathrm{CCl}$ & none & DCM & $\mathrm{nr}$ & - \\
\hline
\end{tabular}

aGeneral conditions: $3 a(0.4 \mathrm{mmol}), \mathbf{4 a}(0.2 \mathrm{mmol}), \operatorname{TrX}(10 \mathrm{~mol} \%)$, and Lewis acid $(10 \mathrm{~mol} \%)$ in $2 \mathrm{~mL}$ solvent at $50{ }^{\circ} \mathrm{C}$. bYield of isolated product. ${ }^{\mathrm{c}}$ Determined by HPLC analysis on a chiral stationary phase. ${ }^{\mathrm{d}}$ Room temperature. ${ }^{\mathrm{e}} 48 \mathrm{~h}$.

activity maintained. The combined use of trityl bromide and 1a (10 mol \%) led to the desired adduct $\mathbf{5 a}$ with 55\% yield and in $14 \%$ ee at $50{ }^{\circ} \mathrm{C}$ (Table 1 , entry 3 ). This is in contrast to the $\mathbf{T P} / \mathrm{InBr}_{3}$ combination where the reaction was much faster but racemic (Table 1, entry 3 vs 2), suggesting that the preformed metal phosphate is critical to effect catalysis and chiral induction. Among the metals screened, Fe(III) phosphate gave the optimal results in terms of both activity and enantioselectivity (79\% yield, 35\% ee, Table 1, entry 5). Fe(III)-based bisphosphate anions were also tested. To our delight, when trityl bromide and 2 a (10 mol \%) were used, the reaction gave a slightly increased enantioselectivity (Table 1, entry 6). Further improvement on activity and enantioselectivity could be achieved by conducting the reaction in DCM as the solvent (Table 1, entries 7 vs $6,8-10)$. Next, we screened different chiral Fe(III) bisphosphates $2 \mathbf{a}-\mathbf{f}$ and the best results were obtained in the pres- ence of $\mathbf{2 f}$, whereas others resulted in either low activity or poor enantioselectivity (Table 1, entries 15 vs 7, 11-14). Eventually, trityl chloride and chiral Fe(III) bisphosphate $\mathbf{2 f}$ were identified to be the optimal combination, affording adduct $\mathbf{5 a}$ in $91 \%$ ee and $70 \%$ yield at room temperature (Table 1, entries 17 and 18).

In a control experiment, we found that chiral iron salt $\mathbf{2 f}$ itself turned out to be ineffective to catalyze the reaction in the absence of trityl chloride (Table 1, entry 19), indicating that the reaction is catalyzed by tritylium salts with $\mathrm{Fe}(\mathrm{III})$-complexed bisphosphate as the chirality-inducing anion.

With the optimal reactions conditions established, the scope was next explored with $\mathrm{Ph}_{3} \mathrm{CCl} / \mathbf{2} \mathbf{f}$ in $\mathrm{CH}_{2} \mathrm{Cl}_{2}$ (DCM) at room temperature and the results are presented in Table 2 . A variety of $\beta, \gamma$-unsaturated $\alpha$-ketoesters 4 was subjected to the reaction 
Table 2: Scope for the asymmetric catalyzed Diels-Alder reaction of anthracene (3a) with ketoesters 4 by carbocations

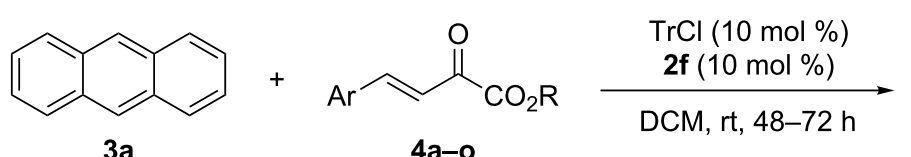

$3 a$<smiles>COC(=O)C(=O)/C=C/c1ccccc1</smiles>

$4 a$<smiles>CCOC(=O)/C=C/c1ccccc1</smiles>

$4 \mathbf{b}$<smiles>CC(C)OC(=O)C(=O)/C=C/c1ccccc1</smiles>

4c<smiles>COC(=O)C=Cc1ccc(F)cc1</smiles>

4d<smiles>CC(=O)C(=O)/C=C/c1ccc(Cl)cc1</smiles>

$4 e$

6<smiles>COC(=O)C=Cc1ccc(Br)cc1</smiles><smiles>COC(=O)C1C2c3ccccc3C(c3ccccc32)C1c1ccccc1</smiles>

$5 a$<smiles>CCOC(=O)[C@H]1C2c3ccccc3C3(c4ccccc42)C2c4ccccc4C213</smiles>

$5 b$<smiles>CC(C)OC(=O)[C@H]1C2c3ccccc3C3(c4ccccc42)C2c4ccccc4C213</smiles>

5c

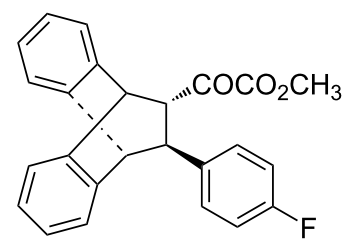

5d<smiles></smiles>

$5 e$

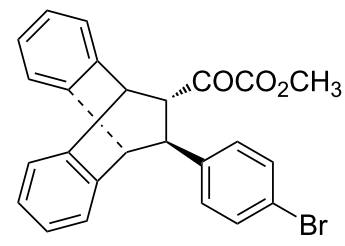

$5 f$

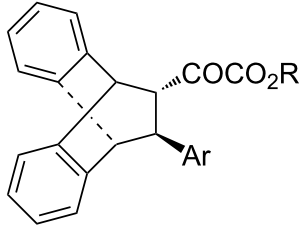

5a-o
70 91

82 74 46 55

74 80 68 75

66 81 
Table 2: Scope for the asymmetric catalyzed Diels-Alder reaction of anthracene (3a) with ketoesters 4 by carbocations. (continued)

7<smiles>CC(=O)C(=O)C=Cc1ccc(C(F)(F)F)cc1</smiles>

$4 \mathrm{~g}$

8<smiles>CC(=O)C(=O)/C=C/c1ccc(I)cc1</smiles>

4h<smiles>CC(=O)C(=O)C=Cc1ccc(-c2ccccc2)cc1</smiles>

$4 i$<smiles>CC(=O)C(=O)/C=C/c1cccc(Cl)c1</smiles>

4j<smiles>CC(=O)C(=O)/C=C/c1cccc(Br)c1</smiles>

$4 k$<smiles>COC(=O)C1C2c3ccccc3C3(c4ccccc4C12)C(C(=O)OC)C3c1cccc(Cl)c1</smiles>

4I

13<smiles>CC(=O)C(=O)/C=C/c1ccc(Cl)c(Cl)c1</smiles><smiles>COC(=O)C1c2ccccc2C2C1c1ccccc1C1(c3ccccc31)C2c1ccc(C(F)(F)F)cc1</smiles>

$5 g$<smiles>COC(=O)C1C2c3ccccc3C(c3ccccc32)C1c1ccc(I)cc1</smiles>

$5 \mathrm{~h}$<smiles>COC(=O)C1C2c3ccccc3C(c3ccccc32)C1c1ccc(-c2ccccc2)cc1</smiles>

5i<smiles>COC(=O)C1C2c3ccccc3C(c3ccccc32)C1c1cccc(Cl)c1</smiles>

5j<smiles>COC(=O)C1C2c3ccccc3C(c3ccccc32)C1c1cccc(Br)c1</smiles>

$5 k$<smiles>COC(=O)C1C2c3ccccc3C3(c4ccccc4C13)C2c1cccc(C)c1</smiles>

5<smiles>COC(=O)C1C2c3ccccc3C3(c4ccccc4C12)C(C(=O)OC)C3c1ccc(Cl)c(Cl)c1</smiles>

$5 \mathrm{~m}$
76

89

77 76

80 93 91 87

86

85 73 
14<smiles>CC(=O)C(=O)/C=C/c1ccc2ccccc2c1</smiles>

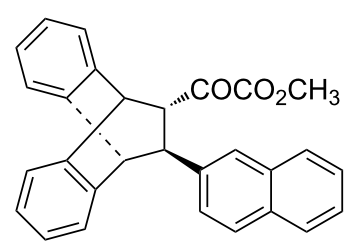

$5 n$
42

83

aGeneral conditions: $\mathbf{3 a}(0.4 \mathrm{mmol}), \mathbf{4}(0.2 \mathrm{mmol}), \operatorname{TrCl}(10 \mathrm{~mol} \%)$, and $\mathbf{2 a}(10 \mathrm{~mol} \%)$ in $\mathrm{DCM}(2 \mathrm{~mL})$ at room temperature. ${ }^{\text {b }}$ Yield of isolated product. ${ }^{\mathrm{C}}$ Determined by HPLC analysis on a chiral stationary phase.

with anthracene (3a) to give the desired cycloadducts $\mathbf{5 a}-\mathbf{n}$ in moderate to good yields and with up to $93 \%$ ee. The bulkier isopropyl ketoester resulted in a lower yield and enantioselectivity (Table 2, entry 3 vs 1 and 2). Variations on the aromatic group of the ketoesters were well tolerated, giving the products in decent yields and high enantioselectivities. Unfortunately, no reaction was observed when an aliphatic substituted $\beta, \gamma$-unsaturated $\alpha$-ketoester was used (data not shown).

The Diels-Alder reaction of substituted anthracenes has been well-developed and we next examined the scope with substituted anthracenes. Unfortunately, these well-explored substrates did not work in our chiral catalysis system giving either no activity or poor enantioselectivity, particularly in cases of 9-monosubstituted anthracenes. When 9,10-dimethylanthracene (3b) was used, the reaction showed high yield (93\% for 5o) but low enantioselectivity ( $23 \%$ ee, Scheme $3 a)$. Surprisingly, the chiral iron salt $\mathbf{2} \mathbf{f}$ itself in the absence of trityl chloride also promoted the reaction, showing a relatively lower activity with $85 \%$ yield of 50 but opposite chiral induction $(-65 \%$ ee, Scheme $3 a)$. The electron-rich nature of dimethylanthracene may account for catalysis with the iron salts. On the other hand, an opposite chiral induction in this case is a clear indication of distinctive carbocation catalysis instead of metal Lewis acid catalysis in the presence of trityl chloride.

In addition, we tested the current carbocation catalytic system to prepare cycloadduct $\mathbf{5 k}$ in a large scale (Scheme $3 b$ ). When<smiles>Cc1c2ccccc2c(Br)c2ccccc12</smiles>

$(0.2 \mathrm{mmol})$

b)<smiles>c1ccc2cc3ccccc3cc2c1</smiles>

$3 a$ (10 mmol)

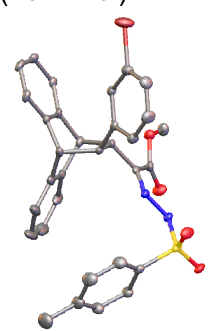<smiles>CC(=O)C(=O)/C=C/c1ccccc1</smiles>

4k

$(0.1 \mathrm{mmol})$

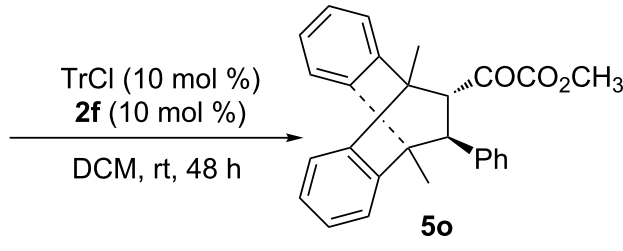

$93 \%, 23 \%$ ee

no $\mathrm{TrCl}: 85 \%,-65 \%$ ee 
using $10 \mathrm{~mol} \% \mathrm{Ph}_{3} \mathrm{CCl} / \mathbf{2}$, the reaction afforded cycloadduct $\mathbf{5 k}$ in $88 \%$ yield of isolated product and with $87 \%$ ee. In the presence of $\mathrm{MgSO}_{4}$ (5 equiv), treatment of $\mathbf{5 k}$ (1 equiv) with sulfonylhydrazine 6 (1.2 equiv) in $\mathrm{CH}_{2} \mathrm{Cl}_{2}$ led to the desired $\mathrm{N}$-tosylhydrazone 7 in $83 \%$ yield and with $82 \%$ ee (Scheme $3 \mathrm{~b}$ ). The absolute configuration was assigned on the basis of the structure of 7, which was confirmed unambiguously by an X-ray crystallographic study [39]. Tentative transition states to account for the observed stereoselectivity are provided in Supporting Information File 1, Figure S3.

\section{Conclusion}

In summary, we have introduced a new motif of chiral weakly coordinating $\mathrm{Fe}$ (III)-based bisphosphate anion for high performance asymmetric carbocation Lewis acid catalysis. The introduction of a metal-coordinated phosphonate anion with balanced association ability with tritylium ions provided a new opportunity in pursuing chiral ion pair-type carbocation catalysis. The resulted asymmetric tritylium catalysis has enabled the so-far challenging Diels-Alder reactions of unsubstituted anthracene with good activity and up to $93 \%$ ee. Further studies are currently underway to elucidate the mechanistic details and to extend the chiral tritylium salt catalysis to other reactions.

\section{Supporting Information}

\section{Supporting Information File 1}

Experimental procedures and characterization data of all products, copies of ${ }^{1} \mathrm{H}$ and ${ }^{13} \mathrm{C}$ NMR, IR, HRMS, and HPLC spectra of all compounds.

[https://www.beilstein-journals.org/bjoc/content/ supplementary/1860-5397-15-129-S1.pdf]

\section{Acknowledgements}

We thank the Natural Science Foundation of China (21390400, 21521002, 21472193) and the Chinese Academy of Sciences (QYZDJ-SSW-SLU023) for financial support. S.L. is supported by the National Program of Top-notch Yong Professionals, and J. L. is supported by the Taishan Scholarship Project of Shandong Province.

\section{ORCID ${ }^{\circledR}$ iDs}

Jian Lv - https://orcid.org/0000-0001-7641-5411

Sanzhong Luo - https://orcid.org/0000-0001-8714-4047

\section{References}

1. Mukaiyama, T.; Kobayashi, S.; Shoda, S.-i. Chem. Lett. 1984, 13, 907-910. doi:10.1246/cl.1984.907

2. Mukaiyama, T.; Kobayashi, S.; Murakami, M. Chem. Lett. 1985, 14, 447-450. doi:10.1246/cl.1985.447
3. Kobayashi, S.; Matsui, S.; Mukaiyama, T. Chem. Lett. 1988, 17, 1491-1494. doi:10.1246/cl.1988.1491

4. Yanagisawa, M.; Mukaiyama, T. Chem. Lett. 2001, 30, 224-225. doi:10.1246/cl.2001.224

5. Roy, S. R.; Nijamudheen, A.; Pariyar, A.; Ghosh, A.; Vardhanapu, P. K.; Mandal, P. K.; Mandal, P. K.; Datta, A.; Mandal, S. K. ACS Catal. 2014, 4, 4307-4319. doi:10.1021/cs5010695

6. Bah, J.; Franzén, J. Chem. - Eur. J. 2014, 20, 1066-1072. doi:10.1002/chem.201304160

7. Bah, J.; Naidu, V. R.; Teske, J.; Franzén, J. Adv. Synth. Catal. 2015, 357, 148-158. doi:10.1002/adsc.201400609

8. Naidu, V. R.; Ni, S.; Franzén, J. ChemCatChem 2015, 7, 1896-1905. doi:10.1002/cctc. 201500225

9. Moosavi-Zare, A. R.; Zolfigol, M. A.; Rezanejad, Z. Can. J. Chem. 2016, 94, 626-630. doi:10.1139/cjc-2015-0629

10. Zhang, Q.; Lü, J.; Luo, S. Acta Chim. Sin. (Chin. Ed.) 2016, 74, 61-66. doi:10.6023/a15090587

11. Lyons, D. J. M.; Crocker, R. D.; Enders, D.; Nguyen, T. V. Green Chem. 2017, 19, 3993-3996. doi:10.1039/c7gc01519d

12. Liu, J.; Xu, J.; Li, Z.; Huang, Y.; Wang, H.; Gao, Y.; Guo, T.; Ouyang, P.; Guo, K. Eur. J. Org. Chem. 2017, 3996-4003. doi:10.1002/ejoc.201700634

13. Zhang, Q.; Lv, J.; Li, S.; Luo, S. Org. Lett. 2018, 20, 2269-2272. doi:10.1021/acs.orglett.8b00619

14. Riant, O.; Samuel, O.; Kagan, H. B. J. Am. Chem. Soc. 1993, 115, 5835-5836. doi:10.1021/ja00066a066

15. Taudien, S.; Riant, O.; Kagan, H. B. Tetrahedron Lett. 1995, 36, 3513-3516. doi:10.1016/0040-4039(95)00531-g

16. Sammakia, T.; Latham, H. A. Tetrahedron Lett. 1995, 36, 6867-6870. doi:10.1016/0040-4039(95)01440-s

17. Chen, C.-T.; Chao, S.-D.; Yen, K.-C.; Chen, C.-H.; Chou, I.-C.; Hon, S.-W. J. Am. Chem. Soc. 1997, 119, 11341-11342. doi:10.1021/ja970900o

18. Magdziak, D.; Pettus, L. H.; Pettus, T. R. R. Org. Lett. 2001, 3, 557-559. doi:10.1021/ol006963k

19. Pommerening, P.; Mohr, J.; Friebel, J.; Oestreich, M. Eur. J. Org. Chem. 2017, 2312-2316. doi:10.1002/ejoc.201700239

20. Lv, J.; Zhang, Q.; Zhong, X.; Luo, S. J. Am. Chem. Soc. 2015, 137, 15576-15583. doi:10.1021/jacs.5b11085

21. Ni, S.; Ramesh Naidu, V.; Franzén, J. Eur. J. Org. Chem. 2016, 1708-1713. doi:10.1002/ejoc.201501621

22. Krossing, I.; Raabe, I. Angew. Chem., Int. Ed. 2004, 43, 2066-2090. doi:10.1002/anie.200300620

23. Strauss, S. H. Chem. Rev. 1993, 93, 927-942. doi:10.1021/cr00019a005

24. Moss, S.; King, B. T.; de Meijere, A.; Kozhushkov, S. I.; Eaton, P. E.; Michl, J. Org. Lett. 2001, 3, 2375-2377. doi:10.1021/ol0161864

25. Anderson, L. L.; Arnold, J.; Bergman, R. G. J. Am. Chem. Soc. 2005, 127, 14542-14543. doi:10.1021/ja053700i

26. Nguyen, T.-T.-T.; Türp, D.; Wagner, M.; Müllen, K. Angew. Chem., Int. Ed. 2013, 52, 669-673. doi:10.1002/anie.201206010

27. Fischer, S.; Schmidt, J.; Strauch, P.; Thomas, A. Angew. Chem., Int. Ed. 2013, 52, 12174-12178. doi:10.1002/anie.201303045

28. Roberts, J. A. S.; Chen, M.-C.; Seyam, A. M.; Li, L.; Zuccaccia, C.; Stahl, N. G.; Marks, T. J. J. Am. Chem. Soc. 2007, 129, 12713-12733. doi:10.1021/ja0680360 
29. Chen, M.-C.; Roberts, J. A. S.; Seyam, A. M.; Li, L.; Zuccaccia, C.; Stahl, N. G.; Marks, T. J. Organometallics 2006, 25, 2833-2850. doi:10.1021/om0508334

30. Metz, M. V.; Sun, Y.; Stern, C. L.; Marks, T. J. Organometallics 2002, 21, 3691-3702. doi:10.1021/om020087s

31. Mager, M.; Becke, S.; Windisch, H.; Denninger, U. Angew. Chem., Int. Ed. 2001, 40, 1898-1902. doi:10.1002/1521-3773(20010518)40:10<1898::aid-anie1898>3.0.co;2$\mathrm{k}$

32. Zhou, J.; Lancaster, S. J.; Walker, D. A.; Beck, S.; Thornton-Pett, M.; Bochmann, M. J. Am. Chem. Soc. 2001, 123, 223-237. doi:10.1021/ja002820h

33. Sun, Y.; Metz, M. V.; Stern, C. L.; Marks, T. J. Organometallics 2000, 19, 1625-1627. doi:10.1021/om990946l

34. Mahlau, M.; List, B. Angew. Chem., Int. Ed. 2013, 52, 518-533. doi:10.1002/anie.201205343

35. Phipps, R. J.; Hamilton, G. L.; Toste, F. D. Nat. Chem. 2012, 4, 603-614. doi:10.1038/nchem.1405

36. Hinz, A.; Labbow, R.; Reiß, F.; Schulz, A.; Sievert, K.; Villinger, A. Struct. Chem. 2015, 26, 1641-1650. doi:10.1007/s11224-015-0638-0

37. Lv, J.; Zhang, L.; Luo, S.; Cheng, J.-P. Angew. Chem., Int. Ed. 2013, 52, 9786-9790. doi:10.1002/anie.201304561

38. Wang, L.; Lv, J.; Zhang, L.; Luo, S. Angew. Chem., Int. Ed. 2017, 56, 10867-10871. doi:10.1002/anie.201704020

39. CCDC 1863542 (7) contains the supplementary crystallographic data for this paper. This data can be obtained free of charge from The Cambridge Crystallographic Data Centre.

\section{License and Terms}

This is an Open Access article under the terms of the Creative Commons Attribution License (http://creativecommons.org/licenses/by/4.0). Please note that the reuse, redistribution and reproduction in particular requires that the authors and source are credited.

The license is subject to the Beilstein Journal of Organic Chemistry terms and conditions:

(https://www.beilstein-journals.org/bjoc)

The definitive version of this article is the electronic one which can be found at: doi:10.3762/bjoc. 15.129 